\title{
Another clue to biotech value
}

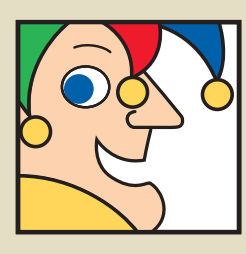

Tom Jacobs, of the Internet site Motley Fool (http://www.fool.com/), provides his angle on biotechnology investments. Read on and become "Foolishly" informed*. He can be contacted about biotechnology and investing at TomJ@Fool.com. Jacobs cannot give individual investment advice but welcomes any.

Last month's column used one common and one not-so-common valuation ratio: price-to-earnings $(\mathrm{P} / \mathrm{E})$ and enterprise value to freecash-flow (EV/FCF; Nat. Biotechnol. 21, 219, 2002). But other ways to determine valuation also deserve attention.

\section{Give it a 'WACC'}

Once armed with ROIC, you can employ another closely guarded trick of analysts for determining the 'opportunity cost' of not investing elsewhere-the weighted average cost of capital (WACC). If you then compare a company's ROIC, say at $23 \%$, to its WACC of $12 \%$, you could say that the company earns 11 cents (23 minus 12 ) in pure economic value for every dollar it invests.

According to Chan, research suggests strongly that stock price appreciation is correlated to the difference between ROIC and WACC and also the trend. Rising or falling ROIC tells you whether the company is doing better or worse investing its (your) money. To see how various biotech companies are doing, see Table 1.

\section{Does management invest better than you?}

Consider that you may invest your cash in countless ways, from stuffing it under the mattress, hoarding gold coins, gambling in Las Vegas, paying down your mortgage, to buying bonds or stocks. The list is long, and every choice presents different risks and potential returns.

When you choose to buy a biotech drugmaker or any other company stock, you risk that the business will at best not reward you, or at worst go bankrupt, and you require greater possible returns for that risk. Economists call this requirement the equity risk premium, or the extra reward investors demand to invest in common stocks instead of, say Treasury bills. So you want biotech company management to invest the company's cash to make drugs - or research tools to enhance drug development- to produce more bang for your buck than investing in risk-free investments. But how do you gauge the skill of management at doing that?

\section{Return on invested capital}

Earnings per share (EPS) tell you a company's accounting profits, and rising revenues certainly indicate the company is selling more product. But "EPS, net income and growth [do] not tell how much capital was invested to generate those numbers," according to McGill Investment Club (Toronto) cofounder Andrew Chan in his paper "The Mechanics of the Economic Model"1.

Most investors simply assume that more revenue and EPS are better, but they are not if they eat up more and more investment to produce them. Return on invested capital (ROIC) attempts to measure how effectively management invests cash. The equation is: ROIC equals net operating profit after taxes divided by average invested capital (or beginning invested capital). That jargon alone and the fact that these are not easily calculated from a company's financial statements explain why ROIC receives far less attention than $\mathrm{P} / \mathrm{E}$ or ratios based on FCF. (For the delightful details of calculating ROIC, see ref. 1.)

\footnotetext{
${ }^{*}$ Nature Biotechnology does not guarantee the veracity, reliability, or completeness of any information provided on this page; it is not responsible for any errors or omissions or for any results obtained from the use of such information; it will not be liable for any loss, damage, or investment decision arising from a reader's reliance on the information provided.
}

Of over 350 companies in the biotechnology and drugs universe, only 73 produced a positive ROIC for the past 12 months. Just about half of those turned in $11 \%$ or above to perhaps be returning above WACC.

A few things stand out. Biogen (Cambridge, MA, USA) and IDEC (San Diego, CA, USA) sport excellent ROICs, but the five-year trend is not good. And on the big pharma side, the Johnson \& Johnson (New Brunswick, NJ, USA; NYSE:JNJ) and Schering-Plough (Kenilworth, NJ, USA; NYSE:SGP) numbers reinforce what you already know: the former invests money better and better, while the now ex-management at Schering was decreasingly adept. Coca-Cola's consistently high ROIC gives you an idea why it consistently sells at a high $\mathrm{P} / \mathrm{E}$.

One caution: ROIC is subject to a number of assumptions, and some unusual events can affect ROIC in the short term but become insignificant if the longer term ROIC trend is good. That said, adding ROIC to the bag of valuation tricks can help you better determine whether a growing company's stock is reasonably priced. An ROIC higher than WACC and still rising shows a high-quality company indeed.

1. http://www.geocities.com/andrewychan/files/EconomicModelV20a.pdf 